\title{
New Carboniferous (Namurian) glaciomarine ostracods from Patagonia, Argentina
}

\author{
PAMELA DÍAZ SARAVIA ${ }^{1}$ \& PETER J. JONES ${ }^{2}$ \\ ${ }^{1}$ Instituto de Paleontologia, Fundación Miguel Lillo, Miguel Lillo 251, 4000 Tucumán, Argentina. \\ ${ }^{2}$ Department of Geology, The Australian National University, Canberra, ACT 0200, Australia.
}

\begin{abstract}
A new ostracod fauna (eight species belonging to five genera) from the lower part of the Levipustula levis Zone of the Pampa de Tepuel Formation, Patagonia is described. It consists of two new species (Aurikirkbya tepuelensis sp.nov., Graphiadactylloides patagoniensis sp.nov.) and six species described informally (Graphiadactylloides sp. aff. G. moreyi Green, G. sp., Mauryella sp., Roundyella? sp. and Scrobicula sp.), including one eridostracan (Cryptophyllus sp.). The assemblage probably lived in a large embayment, in the outer sublittoral (circalittoral) depth biofacies of the continental shelf, on a muddy substrate, within an extraglacial marine facies. Its age is consistent with the currently accepted Early (not earliest) Namurian age for this level. J. Micropalaeontol. 18(2): 97-109, December 1999.
\end{abstract}

\section{INTRODLCTION}

The Pampa de Tepuel Formation, the middle and thickest unit of the Tepuel Group, has provided the most thorough record of Carboniferous marine invertebrate faunas in West Gondwana. Many fossil groups from this fauna have been studied, e.g. brachiopods by Amos (1958), bryozoans by Sabattini (1972, 1983), trilobites by Amos et al. (1960), bivalves by González (1969, 1972a. 1972b, 1975a, 1975b, 1977, 1978, 1981), cephalopods by Miller \& Garner (1953) and Riccardi \& Sabattini (1975), gastropods by Sabattini (1978) and Sabattini \& Noirat (1969) and conularids by Mariñelarena (1970), and these have been collectively referred to the Levipustula Zone, or, more specifically, the Levipustula levis Zone. A complete list of taxa and bibliography on systematic palaeontology is available in Cuneo (1987) and a general correlation of biozones is provided by Archangelsky et al. (1987). To date, only one paper (Rossi de Garcia. 1972) has been published on the Carboniferous ostracods from Argentina.

In a preliminary study, Rossi de Garcia (1972) identified and described Hollinella? sp., Roundyella? sp. and Hypotetragona? sp. from the Late Carboniferous (Silesian) of Patagonia. These identifications were based on only a few samples and specimens, which are lodged at the Museo de La Plata (collection numbers MLP 12457, 12458, 12459). The samples were collected by Dr T. Suero. some 20 years before Rossi de Garcia's paper (1972) was published. They came from a horizon most probably sited at the middle section (LS5 Member) of the Las Salinas Formation in the Languineo hills, on the northern border of the LanguiñeoGenoa Basin. González (1972a) reported Triceratina sp., also from the LS5 Member of Las Salinas Formation, based on a single ostracod specimen (identified by Professor R. C. Whatley).

The Las Salinas Formation is a richly fossiliferous marine offshore and nearshore sequence that is almost equivalent to the Pampa de Tepuel Formation. The LS5 Member may be correlated with the lower richly fossiliferous section of the Pampa de Tepuel Formation (the lower part of the Levipustula levis Zone), which contains the ostracods described in this paper.

The ostracod species described herein form part of a coldwater fauna, associated with the Namurian glaciomarine rocks of Australia and Argentina (Campbell \& McKellar, 1969;

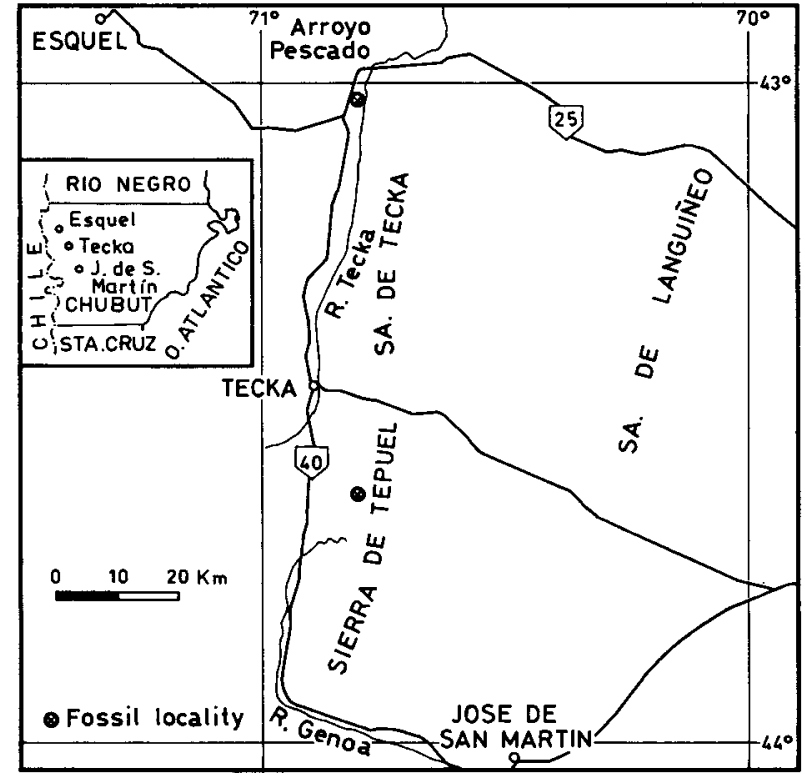

Fig. 1. Location of fossiliferous sites.

González, 1990; Roberts et al., 1995). They provide an independent source of evidence with which to assess the age of the Levipustula Zone, and give additional information on its paleoecology and environment of deposition. All the material is lodged in the Micropalaeontology Section of the Instituto de Paleontologia in the Miguel Lillo Foundation (IPM), Tucumán.

\section{LOCALITIES}

The ostracods described in this paper were collected from two localities (Fig. 1). The first locality was the Tepuel Hills, $30 \mathrm{~km}$ SSE of Tecka and $130 \mathrm{~km} \mathrm{SSE} \mathrm{of} \mathrm{Esquel} \mathrm{at} \mathrm{roughly} 70.66^{\circ} \mathrm{W}$ and $43.83^{\circ} \mathrm{S}$. Here a richly fossiliferous bed (F-Tl-13) $200 \mathrm{~m}$ above the base of the Pampa de Tepuel Formation yielded ostracods in association with other invertebrate groups in the lower part of the Levipustula levis Zone. The second locality was at Arroyo Pescado, $100 \mathrm{~km}$ E of Esquel, at Ap Iwan Farm, where one well-preserved steinkern was found in a thin 
succession of Carboniferous nearshore sediments at the northern border of the Languiñeo-Genoa Basin. This section has been correlated with the previously mentioned LS5 section of Las Salinas Formation (González et al., 1995).

\section{GEOLOGICAL SETTING}

The Tepuel Hills trend $\mathrm{N}-\mathrm{S}$ along the $70^{\circ} 40^{\prime} \mathrm{W}$ meridian and extend along $140 \mathrm{~km}$ between the localities of Tecka and José de San Martin (Fig. 1). They reach a maximum height of $1500 \mathrm{~m}$ above sea level at Cerro Montgomery, the type locality of the Tepuel Group (Suero, 1948), about $30 \mathrm{~km}$ south of Tecka. From base to top, the Tepuel Group encompasses the Jaramillo, Pampa de Tepuel and Mojón de Hierro formations. Except for the southern part of the Tepuel Hills, the Tepuel Group trends $\mathrm{N}-\mathrm{S}$, and is not folded. The base of the sequence is covered and its top is disconformably overlain by Early Jurassic sediments. A brief description of the stratigraphy of the Tepuel Group is given in the following; more detailed descriptions of this interval are provided by Suero (1948) and Page et al. (1984).

The Jaramillo Formation, probably a littoral deposit, consists of $1000 \mathrm{~m}$ of sandstone with minor mudstones and conglomerates. It is poorly fossiliferous and only a few, unidentifiable, brackish water molluscs have been reported (Freytes, 1971; González, 1987); plant remains of Archeosigillaria conferta (Frenguelli) Menéndez are more frequent (Petriella \& Arrondo, 1978). The age of the formation probably ranges from Tournaisian to Early Visean (Azcuy et al., 1990).

The Pampa de Tepuel Formation is a distinct marine sequence, more than $2900 \mathrm{~m}$ thick, consisting of diamictites and dropstone-laminites with intercalated sandstone and wackes - a remarkable record of Gondwana glaciation. It contains an excellent record of marine invertebrates, which are referred to the Levipustula Zone (Andreis et al., 1987, chart 10). Almost all the sediments were deposited in periglacial seas during the Namurian and Westphalian (Suero, 1948; Page et al., 1984; González Bonorino et al., 1988). The lower part of the formation is equivalent to the glacial sequence (San Eduardo Formation) of the Precordilleran region (Calingasta-Upsallata Basin), western Argentina (González, 1993). Here, the San Eduardo Formation consists of three episodes of glaciation and two interglacials, within the Late Visean and Early Namurian interval (González, 1990). The presence of the Levipustula levis Zone in the San Eduardo Formation, in the last glacial episode (Hoyada Verde glaciation) and in its preceding interglacial (González, 1990) indicates a correlation with the lower part of the Pampa de Tepuel Formation.

The Mojón de Hierro Formation consists of mostly sandstone, with some conglomerates and a basal member of blueblack shale. It reaches nearly $500 \mathrm{~m}$ in thickness, being marine at its base and grading to continental sandstone beds bearing the Glossopteris flora at the top. Its uppermost levels may be Sakmarian in age. This formation represents a short-lived rise in sea level recognized on the margin of Gondwana after the Asselian glaciation (Dickins, 1985).

\section{THE LEVIPUSTULA LEVIS ZONE}

The Levipustula levis Zone is a distinct biostratigraphic unit of the Carboniferous marine deposits of Australia and Argentina wherein both regions, it is associated with glacigenic sediments.
In the San Eduardo Formation in the Precordilleran region, western Argentina, the Levipustula levis Zone overlies the Rugosochonetes-Bulahdelia Zone (Taboada, 1989; González, 1990). As the latter zone contains a fauna that can be correlated with the Marginirugus barringtonensis Zone (and possibly the Rhipidomella fortimuscula Zone) of eastern Australia, it was referred to an age about the Visean-Namurian boundary (Roberts et al., 1995). In Argentina, the Levipustula levis Zone is regarded as Namurian-Westphalian (González, 1981, 1993). In Australia, where isotopic dating is available, it is restricted to the Namurian by Roberts et al. (1995). According to these data, the base of the Levipustula levis Zone is probably Early (not earliest) Namurian in age. Ostracods from the Levipustula levis Zone of eastern Australia are present in the collections of the Australian Geological Survey Organisation, Canberra, but are undescribed.

\section{LABORATORY METHODOLOGY}

The material consists of external and internal impressions and steinkerns. Some impressions remarkably preserved delicate details of internal and external structures. The separation and cleaning of ostracods was achieved using a number of laboratory procedures; rock cover was mechanically removed with a thin needle, although fragile specimens may be broken by using this method. In the case of bulk samples, chemical techniques were used: the material, previously disaggregated by pressure, was immersed in hydrogen peroxide or acetic acid. Casts were made following the technique described by Siveter (1982), but using vinylpolysiloxane, as suggested by Leiggi (1989). The advantages of this method are more rapid casting and excellent replication of delicate microsculpture. Specimens were mounted on a brass stub, gold-coated and photographed using a JEOL-JSM3 scanning electron microscope housed at the Fundación Miguel Lillo, Argentina.

\section{PALAEOECOLOGY OF THE OSTRACOD FAUNA}

The ostracod specimens are numerically common (115) in samples from $200 \mathrm{~m}$ above the base of the Pampa de Tepuel Formation, where they are randomly distributed in small lenses within wackes and dropstone mudstones between diamictites. These sediments were deposited in circalittoral environments, ranging from proglacial to extraglacial (sensu Brodzikowski \& Van Loon, 1987). Our study of the fauna delineates eight benthic species belonging to five genera. Palaeocopida are represented by one kirkbyacean (Aurikirkbya tepuelensis sp.nov.), one drepanellacean (Mauryella sp.) and two superfamiliae incertae (Roundyella? sp. and Scrobicula sp.). Podocopida (Metacopina) are represented by three quasillitaceans (Graphiadactylloides patagoniensis sp.nov., G. sp. aff. G. moreyi Green, $G$. sp.). The Eridostraca (Branchiopoda?) are represented by Cryptophyllus sp.

Palaeobathymetric studies of ostracods in Recent sediments of the continental shelf and upper slope of the Gulf of Alaska (Brouwers, 1988a, 1988b) provide a modern analogue with which to assess the depth conditions of the Carboniferous ostracods of Patagonia, but such endeavours are constrained by the marked taxonomic contrast between Carboniferous and Recent genera and species, and the hazards of unjustifiable extrapolation. However, some general characterizations, such as 
species richness (number of species) and abundance (number of specimens), may be relevant to the present study. Thus, a comparison of the ratios of the average number of species to the average number of specimens (Brouwers, 1988a, table 1) suggests that the outer sublittoral depth biofacies $(0.095$; $N=12.6$ species, 132 specimens) is the value closest to that of the Carboniferous ostracod (and eridostracan) fauna of the Pampa de Tepuel Formation $(0.070 ; N=$ eight species, 115 specimens). In the Alaskan analogue, the values for this ratio in the inner sublittoral depth biofacies $(0.031 ; N=14.4$ species, 464 specimens) and the middle sublittoral depth biofacies $(0.033$; $N=16.7$ species, 503 specimens) are considerably lower (Brouwers, 1988a, table 1). This similarity perhaps implies comparable ecological conditions for both locations, viz. high nutrient levels and probably substantially high sedimentation rates.

The present material was considered unsuitable for species population structure studies, a necessary requirement to determine whether or not the fauna had been transported, either entirely or in part, from its original habitat into its environment of deposition. However, the surface relief of the specimens do not bear any marked evidence of abrasion, which suggests that the fauna probably represents a biocoenosis, and that post-mortem transportation, if it occurred, would have been minimal. More than $70 \%$ of the specimens belong to three species: Aurikirkbya tepuelensis sp. nov. (numerically, the dominant species), Graphiadactylloides patagoniensis sp. nov. and Cryptophyllus sp. This high proportion of individuals to species, and low species diversity, indicates deposition in a lowenergy environment, probably below the wave base.

The notion that this benthic ostracod fauna is a biocoenosis that occupied a circalittoral depth biofacies is supported by the palaeoautecological interpretations of the Kirkbyidae and Scrobiculidae by several workers (as summarized by Melnyk \& Maddocks, 1988). The Kirkbyidae, especially Aurikirkbya, were predominantly offshore crawlers and swimmers that lived on a substrate of firm calcareous mud (Melnyk \& Maddocks, 1988). The Scrobiculidae were shallow shelf (middle sublittoral), possibly vagile benthic dwellers on calcareous terrigenous mud (Melnyk \& Maddocks, 1988). The Quasillitidae (e.g. Graphiadactyllis, Graphiadactylloides), are found in sediments deposited near the shelf break between the outer shelf and slope in Early Carboniferous sequences in North America and Europe. In the Upper Mississippi Valley this family is well represented in the feather-edge of the Fern Glen Formation and in the condensed sequence off-shelf equivalent of the State Pond Member of the Springville Shale (Benson \& Collinson, 1958; Lane, 1978). A similar palaeobathymetric relationship for this family is present in the Banff Formation, western Canada (Green, 1963), and in the Late Tournaisian subsurface rocks of the German Baltic islands of Rügen and Hiddensee (Blumenstengel, 1975; Gründel, 1975). Two depth biofacies have been suggested for the eridostracan Cryptophyllus, i.e. deep platform biofacies in the middle Ordovician of North America (Copeland, 1982) and the marine nearshore realm in the Late Devonian of western Europe (Bless, 1983) and the Late Devonian and Early Carboniferous of Western Australia (Jones, 1989).

The balance of the palaeoecological evidence from the ostracods suggests that they lived in the outer sublittoral (circalittoral) depth biofacies, on a muddy substrate. Most probably, the entire Levipustula fauna lived in a large embayment, on the continental shelf, within an extraglacial marine facies. This scenario agrees with the one proposed by González (1984) i.e. a shallow marine environment affected by glaciers. It also concurs with observations by González Bonorino et al. (1988). The low-diversity, highly provincial, Levipustula fauna has been regarded as a 'cold fauna' because of its association with glaciomarine sediments (González, 1990; Roberts et al., 1995).

\section{AGE OF THE OSTRACOD FAUNA}

The species described in this paper belong to genera that are known from Late Palaeozoic deposits elsewhere in the world, and a study of the combined stratigraphic ranges of these genera allows some indication of the age of the fauna.

Aurikirkbya ranges from the Pennsylvanian to the Late Permian (Becker, 1997c) and is recorded from North America, Spain, China and, doubtfully, from Japan. Mauryella ranges from Late Devonian (Frasnian) to Mississippian (Chesterian) in North America, and in Europe it appears to be restricted to the latest Devonian of Germany and Poland. Graphiadactylloides appears to be restricted to the Mississippian in North America. The only recorded European species, G. slowikensis Olempska, 1981 from the Tournaisian of Poland, is now referred by Olempska (1997) to the genus Ovatoquasillites. Graphiadactylloides was originally described from the Lower Mississippian of Canada (Green, 1963). G. axea (Brayer, 1952), the youngest recorded species of the genus (Green, 1963), was described from the Salem Limestone of Missouri, a formation which is Meramecian (mid-Visean) in age (Baxter \& Brenckle, 1982). The genus Roundyella occurs in Early Carboniferous to Permian sediments of Europe, and in Mississippian to Permian sediments of North America (Sohn, 1961b). Scrobicula is reported in the Middle Devonian of North America, in the Tournaisian to Namurian of Europe (Sohn, 1961b) and in the Visean of Australia (Jones, 1989). The eridostracan Cryptophyllus has a more extended range; it is recorded from the Ordovician to Late Devonian in North America and Europe, and from the Early Devonian to Early Carboniferous (Visean) of Australia and North Africa (Bless \& Massa, 1982; Jones, 1962, 1968, 1989). In South America, Cryptophyllus has been described from the Lower Devonian Talacasto Formation in the San Juan Province (Baldis \& Rossi de Garcia, 1975), the Lower Ordovician 'Emposadense Horizonte' in the Mendoza Province (Schallreuter, 1981, 1996) of Argentina, and the Middle Ordovician (Llanvirn) Contaya Formation of Peru (Siveter, in Hughes et al. 1980). The youngest known occurrence of Cryptophyllus is in the Upper Visean of western Libya (Bless \& Massa, 1982).

Given the wide stratigraphic ranges of these genera, the most useful are those of Aurikirkbya and Mauryella. So far, Aurikirkbya has not been recorded from rocks older than basal Pennsylvanian (Morrowan) and Mauryella has not been recorded from rocks younger than uppermost Mississippian (Chesterian). Thus the association of these two genera in the lower part of the Pampa de Tepuel Formation suggests that their age lies somewhere about the Mississippian-Pennsylvanian boundary. It also indicates that the species of Graphiadactylloides from the Levipustula Zone of Patagonia now represents 
the youngest known occurrence of the genus. The evidence is weighted in favour of a Late Mississippian age by the presence of Mauryella, Scrobicula and the eridostracan Cryptophyllus, which are all unknown in the Pennsylvanian. Furthermore, the new species of Aurikirkbya appears to be a morphologically less developed form of the Aurikirkbya branch of the Kirkbya line, which indicates that the host rock is more likely to be Late Mississippian, than Early Pennsylvanian.

We conclude, therefore, that the age indicated by the ostracods in the base of the Levipustula levis Zone is consistent with the currently accepted Early (not earliest) Namurian age for this level.

\section{PALAEOBIOGEOGRAPHY}

During the Late Visean-Westphalian Gondwanan 'ice age', the lowlands of the western belt of Argentina were probably covered by extensive ice sheets (Keidel, 1922; González, 1990). Patagonia was especially affected by glaciers because this region was closer to the south palaeopole (Valencio, 1973). This period is recorded in the Pampa de Tepuel Formation, which was deposited into a broad 'Pacific' embayment in central Patagonia. As can be deduced from associated faunal assemblages and lithofacies, marine water temperatures flucuated in response to the alternation of glacial and interglacial periods during the deposition of the Pampa de Tepuel Formation, and these conditions probably lasted from Late Visean to Early Namurian, and probably into the Westphalian.

The presence of Aurikirkbya, Graphiadactylloides and Mauryella in the Pampa de Tepuel Formation represents the most southerly location of North American-type genera along the continental margin of western Gondwana. They presumably migrated southwards, aided by currents, along the shelf margins of the juxtaposed Laurentian and Western Gondwana blocks. In view of the marked palaeotemperature gradient between the palaeoequatorial belt and the polar region of central Patagonia, these genera were probably sufficiently tolerant to changes in water temperature to adapt to the cold-water milieu of the more provincial Levipustula fauna.

\section{CONCLUSIONS}

A new ostracod fauna is present in the lower part of the Pampa de Tepuel Formation, in the Languiñeo-Genoa Basin, central Patagonia. It is the second described ostracod fauna from the basin, the first being that described from the Las Salinas Formation (Rossi de Garcia, 1972).

The age indicated by the ostracod fauna is consistent with the currently accepted Early (not earliest) Namurian age for the base of Levipustula levis Zone. Most probably the ostracods lived in a large embayment, in the outer sublittoral (circalittoral) depth biofacies of the continental shelf, on a muddy substrate, within an extraglacial marine facies. The ostracods were probably sufficiently tolerant to changes in water temperature to adapt to the cold-water milieu of the more provincial Levipustula fauna.

\section{SYSTEMATIC DESCRIPTIONS}

The following abbreviations are used in the descriptions: $\mathrm{C}=$ carapace; $\mathrm{s}=$ steinkern; 1 or $\mathrm{LV}=\mathrm{left}$ valve; $\mathrm{r}$ or $\mathrm{RV}=$ right valve; $\mathrm{v}=$ ventral view; $\mathrm{h}=$ holotype; $\mathrm{A}=$ pre- sumed adult stage; $\mathrm{j}=$ juvenile; $\mathrm{L}=$ length; $\mathrm{H}=$ height; $\mathrm{W}=$ width; and $\mathrm{H} / \mathrm{L}=$ height/length ratio. All dimensions are given in millimetres $(\mathrm{mm})$. Because all the illustrated specimens are casts of external impressions, their dimensions (and possibly outline) are approximate.

Order Palaeocopida Henningsmoen, 1953

Suborder Palaeocopina Henningsmoen, 1953

Superfamily Kirkbyacea Ulrich \& Bassler, 1906

Remarks. The classification of the Kirkbyacea has been recently revised in a series of papers by Becker (1990, 1997a-d, 1998a,b). In this paper, we concur with his concept of the phylogeny of the Kirkbyacea as 'a well-defined, homogenous group containing most advanced palaeocopines, with its roots in post-Ordovician drepanellids.' We also use his terminology (Becker, 1997a, 1998 b) to describe the adventral structures in the Kirkbyacea.

\section{Family Kirkbyidae Ulrich \& Bassler, 1906 \\ Genus Aurikirkbya Sohn, 1954}

Type species. Kirkbya wordensis Hamilton, 1942.

Diagnosis. (Adapted from Becker, 1997c). Kirkbyidae with lateral lobes and subcentral connecting lobe; lobes well defined to subdued; adventral structures (marginia, velum) prominent (thickened ridges, tubular frills); adductorial pit (spot) distinctly defined below connecting lobe; aggregate adductor muscle scars known.

Stratigraphic range. Pennsylvanian to Upper Permian (Becker, 1997c)

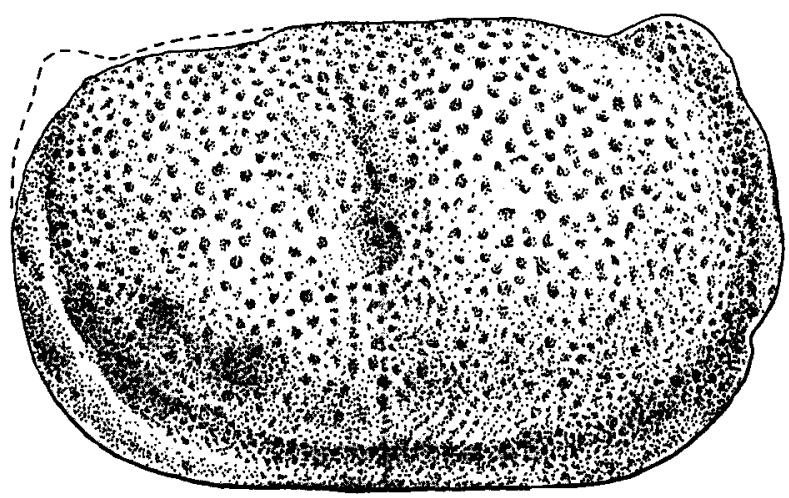

Fig. 2. Lateral view of right valve of Aurikirkbya tepuelensis sp nov. showing details of marginal carina, kirkbyan pit and reticulate ornament.

Aurikirkbya tepuelensis sp.nov.

(Plate 1, figs 1-10; Fig. 2)

Derivation of name. From Tepuel Hills.

Diagnosis. Aurikirkbya species with subdued lobation, welldeveloped subcentral rounded adductorial pit, and thickened, outer frill-like carina.

Holotype. IPM 001/06 
Namurian ostracods from Patagonia
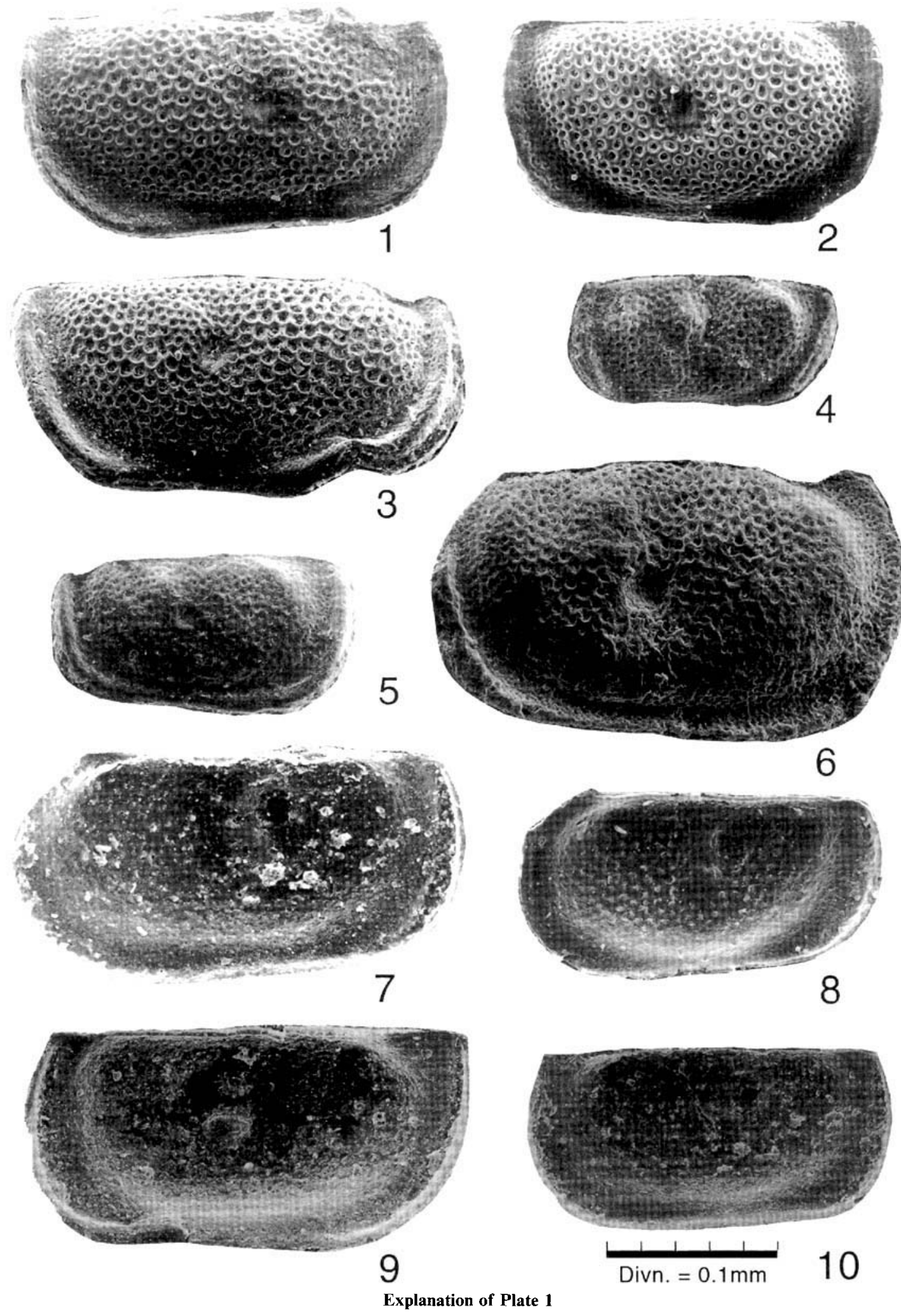

figs 1-10. Aurikirkbya tepuelensis sp.nov. fig. 1. Right lateral view, IPM001-10, fig. 2. Left lateral view, IPM001-47. fig. 3. Left lateral view showing post-depositional deformation, IPM001-14. fig. 4. Left lateral view, IPM001-41. fig. 5. Left lateral view, IPM001-05. fig. 6. Left lateral view, with broken anterior cardinal corner, holotype IPM001-06. fig. 7. Right lateral view, with broken posterior cardinal corner, IPM001-03. fig. 8. Right lateral view, with broken posterior cardinal corner, IPM001-04. fig. 9. Left lateral view, IPM001-02. fig. 10. Right lateral view, IPM001-01. All specimens from locality F-T1-13, Tepuel Hills, Tepuel Formation; vinylpolyxyloxane casts. Magnification $\times 55$. 
Material. Eighty well-preserved external impressions. IPM001/ 01-80.

Type locality and horizon. Tepuel Hills, $30 \mathrm{~km}$ south of Tecka, Chubut province. $200 \mathrm{~m}$ above the base of Pampa de Tepuel Formation. Lower Levipustula levis Zone, Early Namurian.

Description. Carapace large, lateral outline subquadrate to elongate. Dorsal border straight, with moderately developed posterior shoulder. Posterior cardinal angle $90^{\circ}$ or slightly more; anterior cardinal angle slightly greater. Ventral margin nearly straight, inclined posteriorly. Anterior and posterior ends rounded. Greatest height behind midlength; greatest length at midheight. Outer carina, frill-like, thickened, with radial ribs; inner carina, narrow frill closer to the free margin. Curvature of lateral surface interrupted by subdued lobation. Surface reticulate, consisting of rows of fossae subparallel to outer carina. Adductorial pit rounded, large, well developed in subcentral area.

$\begin{array}{lllll}\begin{array}{l}\text { Dimensions. } \\ \text { Specimen }\end{array} & L & H & H / L & \text { Material } \\ \text { IPM 001-10 } & 1.29 & 0.62 & 0.48 & \text { Ar Pl. 1, fig. 1 } \\ \text { IPM 001-47 } & 1.13 & 0.54 & 0.49 & \text { Al Pl. 1, fig. 2 } \\ \text { IPM 001-14 } & 1.30 & 0.65 & 0.50 & \text { Al Pl. 1, fig. 3 } \\ \text { IPM 001-41 } & 0.78 & 0.38 & 0.48 & \text { jl Pl. 1, fig.4 } \\ \text { IPM 001-05 } & 0.87 & 0.40 & 0.46 & \text { jl Pl. 1, fig.5 } \\ \text { IPM 001-06 } & 1.35 & 0.82 & 0.60 & \text { Alh Pl. 1, fig. 6 } \\ \text { IPM 001-03 } & 1.30 & 0.60 & 0.46 & \text { Al Pl. 1, fig. 7 } \\ \text { IPM 001-04 } & 1.05 & 0.44 & 0.42 & \text { jl Pl. 1, fig. 8 } \\ \text { IPM 001-02 } & 1.25 & 0.55 & 0.44 & \text { Al Pl. 1, fig. 9 } \\ \text { IPM 001-01 } & 1.05 & 0.45 & 0.43 & \text { jr Pl. 1, fig.10 }\end{array}$

Remarks. The variation in the range of the $H / L$ ratios $(0.42-$ 0.60) may indicate, but does not prove, that proportional dimorphism exists in this species. This type of dimorphism has not been recorded in the Kirkbyacea.

The radial ribs of the outer carina and the 'aurikirkbyid lobation' are much less developed in Aurikirkbya tepuelensis sp.nov than they are in the Westphalian species $A$. hispanica Becker, Bless \& Sanchez de Posada, 1977, as figured by Becker (1978). With respect to these features, $A$. tepuelensis is morphologically closer to A. triseriata Shaver, 1959 (see Shaver \& Smith, 1974, for a summary of the complex taxonomic history of this species), but, even then, its lobation is more subdued than that of the juvenile specimen figured by Sohn (1983, pl. 11, figs 5 , 6) as Aurikirkbya spp. ex gr. A. triseriata Shaver, 1959. For this reason, we regard $A$. tepuelensis as an early representative of the Aurikirkbya branch, close to the Kirkbya evolutionary line (see Becker 1997a, fig. 1).

Superfamily Drepanellacea Ulrich \& Bassler, 1923 Family Aechminellidae Sohn, 1961

Genus Mauryella Ulrich \& Bassler, 1923

Diagnosis. Aechminellidae with six to eight rounded nodes superimposed on a reticulated valve.

Type species. Mauryella mammillata Ulrich \& Bassler, 1923

Discussion. The genus Mauryella includes Verrrucosella Croneis \& Gale, 1938 (type species V. golcondensis Croneis \& Gale, 1938) as a junior synonym (Sohn, 1961a). This species possesses eight nodes. Mauryella resembles the nodose genus Cornigella Warthin, 1930 (type species C. minuta Warthin, 1930), but lacks the single upward pointing large spine near the dorsal margin that is characteristic of that genus. Polytylites quincollina (Harlton, 1929) was originally described as a species of Mauryella with five nodes, but the large central lobe indicates a kirkbyacean (amphissitid) relationship (Sohn, 1962).

Stratigraphic range. Late Devonian (Frasnian) based on $M$. sola Loranger, 1963 from Alberta, Canada, to Late Mississipian (Chesterian) based on $M$. golcondensis (Croneis \& Gale, 1938) from Illinois, USA. Cooper (1941) gives the upper limit of the stratigraphic range of this species as Menard Limestone, which, in Western European terms, is Early Namurian (about the Pendleian-Arnsbergian boundary).

\section{Mauryella sp. (Plate 2, Fig. 4)}

Material. Two specimens, IPM003/01 and IPM003/02 (unfigured).

Locality and horizon. As for Aurikirkbya tepuelensis sp. nov. Description. Valve small, subovate, slightly preplete in lateral view. Dorsal border straight, with distinct cardinal angles. Free border gently convex in posterior and ventral parts, truncated in anterior part. Lateral surface reticulate with six rounded nodes and a subdued $(\mathrm{S} 2)$ sulcus. Figured $\mathrm{LV}=0.63 \mathrm{~L}, 0.32 \mathrm{H}$.

Remarks. The specimens to hand resemble the type species as described and figured by Benson \& Collinson (1958) from the early Osagean of Illinois. These workers distinguished the primary characters of the adult stage of $M$. mammillata by the presence of "six rounded nodes, a reticulate surface pattern on a straight hinged, anteriorly swung carapace with a very subdued $\mathrm{S} 2$ sulcus'. If the position of $\mathbf{S} 2$ is indicative of the anterior half of the carapace, then the orientation of this species used by Benson \& Collinson (1958, fig. 14) should be reversed. The orientation of Mauryella sp. used here is the same as that used by Olempska (1997, fig. 9a-c) for $M$. polonica Olempska, 1997, described from the latest Famennian in the Holy Cross Mountains, Poland. The Patagonian species is also similar to $M$. polonica in the number, position and size of nodes, but differs in lateral outline. $M$. sp. may be new, but the material available is insufficient for formal description.

Superfamily uncertain

Family Scrobiculidae Posner 1951, emend Gramm 1976

Diagnosis. (After Jones, 1989). Small, subquadrate or suboval inequivalved ( $\mathrm{R} / \mathrm{L}$ overlap) carapace, and a simple rectodont hinge structure. Free margin without duplicature, homogeneous, with an uninterrupted contact groove. Outer lamella with many normal pores; external surface reticulate, pitted, rugate, occasionally tuberculate. Adductor muscle scar oval, transversely elongated, often pear-shaped, consisting of three or four fair indistinct rows, total number of spots 13 to 24 ; frontal spot present, during ontogeny the anterior spots are the first to appear.

Stratigraphic range. Middle Devonian to Upper Carboniferous (Namurian). 


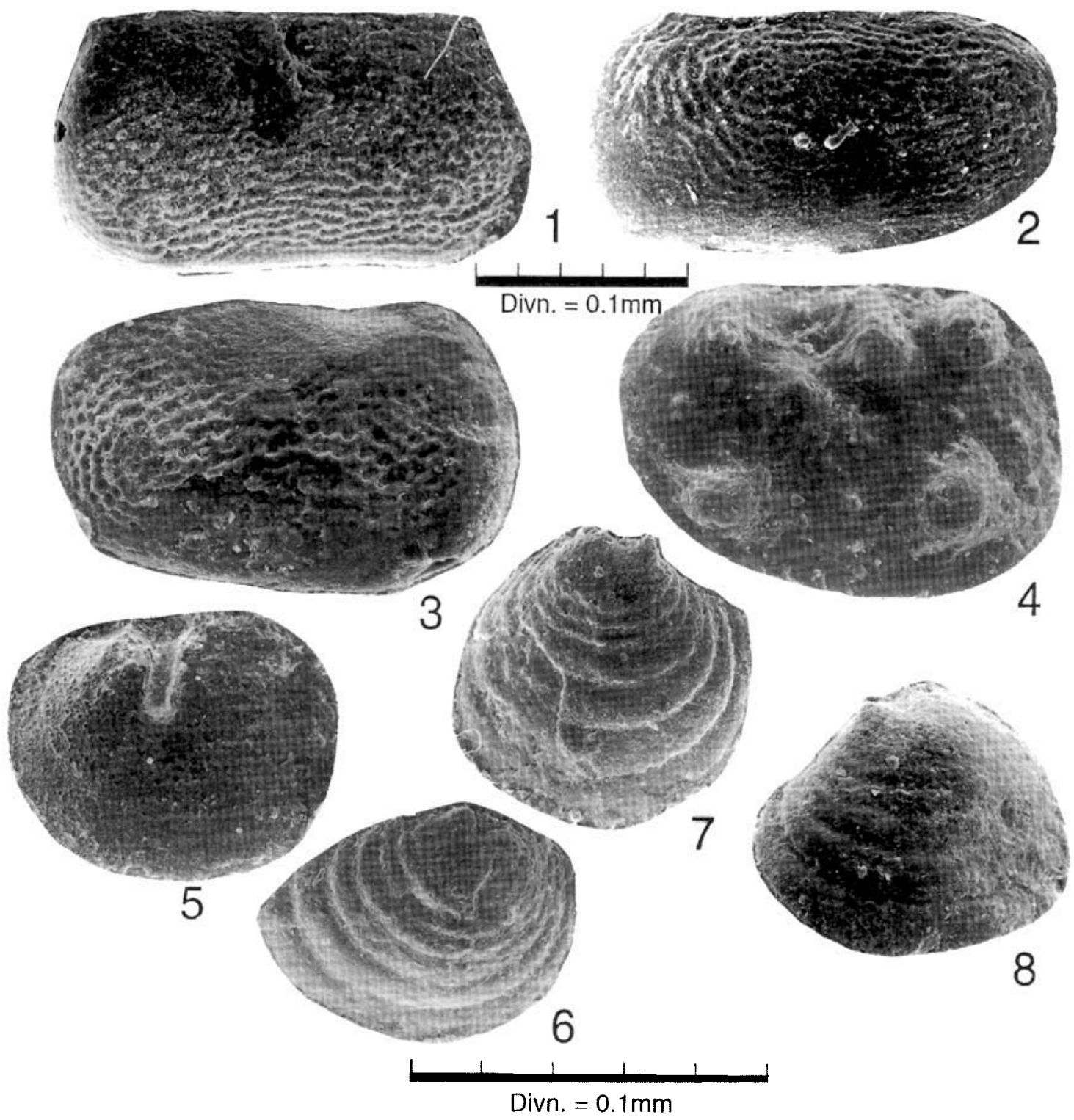

Explanation of Plate 2

figs 1, 2. Roundyella? sp. fig. 1. Lateral view showing reticulated surface, IPM004-02 $\times 60$. fig. 2. Lateral view, IPM004-01 $\times 60$. fig. 3. Scrobicula sp. lateral view showing reticulate sculpture and developed pit, IPM005-01 $\times 100$. fig. 4. Mauryella sp. reticulate surface and rounded nodes on lateral LV, IPM003-01 $\times 100$. figs 5-8. Cryptophyllus sp. fig. 5. Internal mould, detail of umbonal ridges, IPM002-02 $\times 100$. fig. 6. Upper view showing grooves and ridges and umbonal sulcus and spines, IPM002-01 $\times 100$. fig. 7. Upper lateral view showing umbonal spine and sulcus, IPM002-03 $\times 100$. fig. 8. Tilted lateral view of external mould, IPM002-04×100. All specimens are vinylpolyxyloxane casts from locality F-T1-13, Tepuel Hills, Tepuel Formation.

Genus Scrobicula Posner, 1951

Type species. Cytherella? scrobiculata Jones, Kirkby \& Brady, 1884

\section{Scrobicula sp.}

(Plate 2, Fig. 3)

Material. One specimen, external impression. IPM005/01. Locality and horizon. As for Aurikirkbya tepuelensis sp. nov.
Description. Carapace small, suboval to subelliptical in lateral view. Dorsal margin gently curved; ventral margin evenly concave, anterior and posterior ends arched. External surface reticulate, consisting of fine punctae concentrically arranged, that decrease through to the margins. Subcentral smooth muscle scars. Estimated dimensions $0.66 \mathrm{~L}, 0.40 \mathrm{H}$.

Remarks. This specimen shows some resemblance with $S$.? aff. inaequalis Jones, 1989, described from the Late Visean of the Bonaparte Basin, Western Australia, but more material is 
necessary for a closer comparison.

$$
\text { Family Roundyellidae Gramm, } 1976
$$

Diagnosis. (After Gramm, 1976). Small, subrectangular, inequivalved $(\mathrm{R} / \mathrm{L}$ overlap) carapace, and a simple rectodont hinge structure. Free margin without duplicature, homogeneous, with an uninterrupted contact groove. Outer lamella with many normal pores; surface reticulate, with fairly numerous thin spines. Adductor muscle scar rounded, consisting of three or four inner spots surrounded by seven to nine peripheral spots; during ontogeny the inner spots emerge first.

Genus Roundyella Bradfield, 1935

Type species. Amphissites simplicissimus Knight, 1928.

Diagnosis. (After Sohn, 1961). Straight-backed, reticulated or papillose small ostracodes with subcentral smooth muscle spot and without marginal ridges.

Stratigraphic range. Devonian to Late Permian.

Roundyella? sp.

(Plate 2, Figs 1 and 2)

Material. Two specimens, IPM004/ 01,02. external impressions. Locality and horizon. As for Aurikirkbya tepuelensis sp. nov. Description. Outline subrectangular. Dorsal margin straight. Ventral border subparallel to dorsal. Anterior and posterior ends rounded. External surface reticulated, with longitudinal rows, forming fossae polygonal to rounded in shape, and aligned subparallel to margins. Inconspicuous muscle scars like a smooth subcentral spot.

$\begin{array}{llll}\text { Dimensions. (estimated) } & & \\ \text { Specimen } & L & H & \text { Material } \\ \text { IPM 004-01 } & 1.10 & 0.59 & \mathrm{Ar} \\ \text { IPM 004-02 } & 1.12 & 0.59 & \mathrm{Al}\end{array}$

Remarks. These specimens are questionably assigned to the genus Roundyella, because insufficient material is available for study. Roundyella? sp. Rossi de Garcia (1972) has antero-ventral and postero-ventral spines, which are absent in the species described in this paper.

Order Podocopida Müller, 1894

Suborder Metacopina Sylvester-Bradley, 1961

Superfamily Quasillitacea Coryell \& Malkin, 1936

Family Quasillitidae Coryell \& Malkin, 1936

Genus Graphiadactylloides Green, 1963
Type species. Graphiadactylloides moreyi Green, 1963.

Remarks. Green (1963) proposed the genus Graphiadactylloides as a morphological intermediate between Quasillites and Graphiadactyllis, to include those species formerly placed in Graphiadactyllis, which possess postero-ventral spines and welldeveloped marginal flanges, but lack posterior shoulders.

Stratigraphic range. Mississippian (Osagean-Meramecian) of North America.

Graphiadactylloides patagoniensis sp. nov. (Plate 3, figs 1-8)

Derivation of name. With reference to the region of origin, Patagonia.

Diagnosis. Graphiadactylloides species with subrhomboidal to oval lateral outline, lateral surface ornament with fingerprint pattern, without anterior marginal flange.

Holotype. IPM006/03.

Material. Twentyfour well-preserved external impressions. IPM006/ 01-24.

Type locality and horizon. As for Aurikirkbya tepuelensis sp. nov. Description. Carapace large, lateral outline subrhomboidal to oval. Dorsal border straight, or slightly curved in posterior half. Anterior cardinal angle greater than posterior cardinal angle. Greatest height slightly behind anterior border; greatest length at mid-height; greatest width at mid-length position. Ventral border straight. Anterior and posterior ends rounded. Lateral surface ornamented by inosculating fine ribs, arranged in fingerprint pattern; ribs almost parallel to free margins. LV larger than RV, with moderate $L / R$ overlap. Spines well developed at postero-ventral corner in both valves.

$\begin{array}{lllll}\text { Dimensions. } & & & & \\ \text { Specimen } & L & H & H / L & \text { Material } \\ \text { IPM 006-03 } & 1.70 & 0.89 & 0.52 & \text { Arh P1. 3, fig. 1 } \\ \text { IPM 006-02 } & 1.65 & 0.85 & 0.51 & \text { Al Pl. 3, fig. 2 } \\ \text { IPM 006-05 } & 1.80 & & & \text { Av Pl. 3, fig. 3 } \\ \text { IPM 006-06 } & 1.50 & 0.70 & 0.47 & \text { Al Pl. 3, fig. 4 } \\ \text { IPM 006-04 } & 1.55 & 0.70 & 0.45 & \text { Al Pl. 3, fig. 5 } \\ \text { IPM 006-11 } & 1.75 & & & \text { Av Pl. 3, fig. 6 } \\ \text { IPM 006-17 } & 1.40 & 0.62 & 0.44 & \text { Al Pl. 3, fig. 7 } \\ \text { IPM 006-01 } & 1.60 & 0.69 & 0.43 & \text { Al Pl. 3, fig. 8 }\end{array}$

Remarks. Graphiadactylloides patagoniensis sp. nov. is similar in lateral outline and ornamentation to G. striatoreticulatus Green, 1963, described from the lower and middle Banff Formation (Kinderhookian) of Alberta, Western Canada. It is larger than the Canadian species, which is probably based on juvenile instars, and lacks the characteristic antero-ventral spine and central smooth spot.

\section{Explanation of Plate 3}

figs 1-8. Graphiadactylloides patagoniensis sp. nov. fig. 1. Left lateral view, showing strong R/L overlap, holotype IPM006-03. fig. 2. Right lateral view, IPM006-02. fig. 3. Tilted dorsal view, showing straight depressed hinge-line, lateral surface sculpture and posteroventral spine on left valve, IPM006-05. fig. 4. Left lateral view, IPM006-06. fig. 5. Left lateral view, IPM006-04. fig. 6. Tilted ventral view showing lateral surface sculpture and posterior spine on right valve, IPM006-11. fig. 7. Right lateral view, IPM006-17. fig. 8. Right lateral view, IPM006-01. fig. 9. Graphiadactylloides sp. left lateral view of steinkern, IPM006-26, Arroyo Pescado (Ea. Ap-Iwan). fig. 10. Graphiadactylloides sp. aff. G. moreyi Green, right lateral view, IPM006-25. All specimens are vinylpolyxyloxane casts from locality F-T1-13, Tepuel Hills, Tepuel Formation unless stated otherwise. Magnification $\times 40$. 

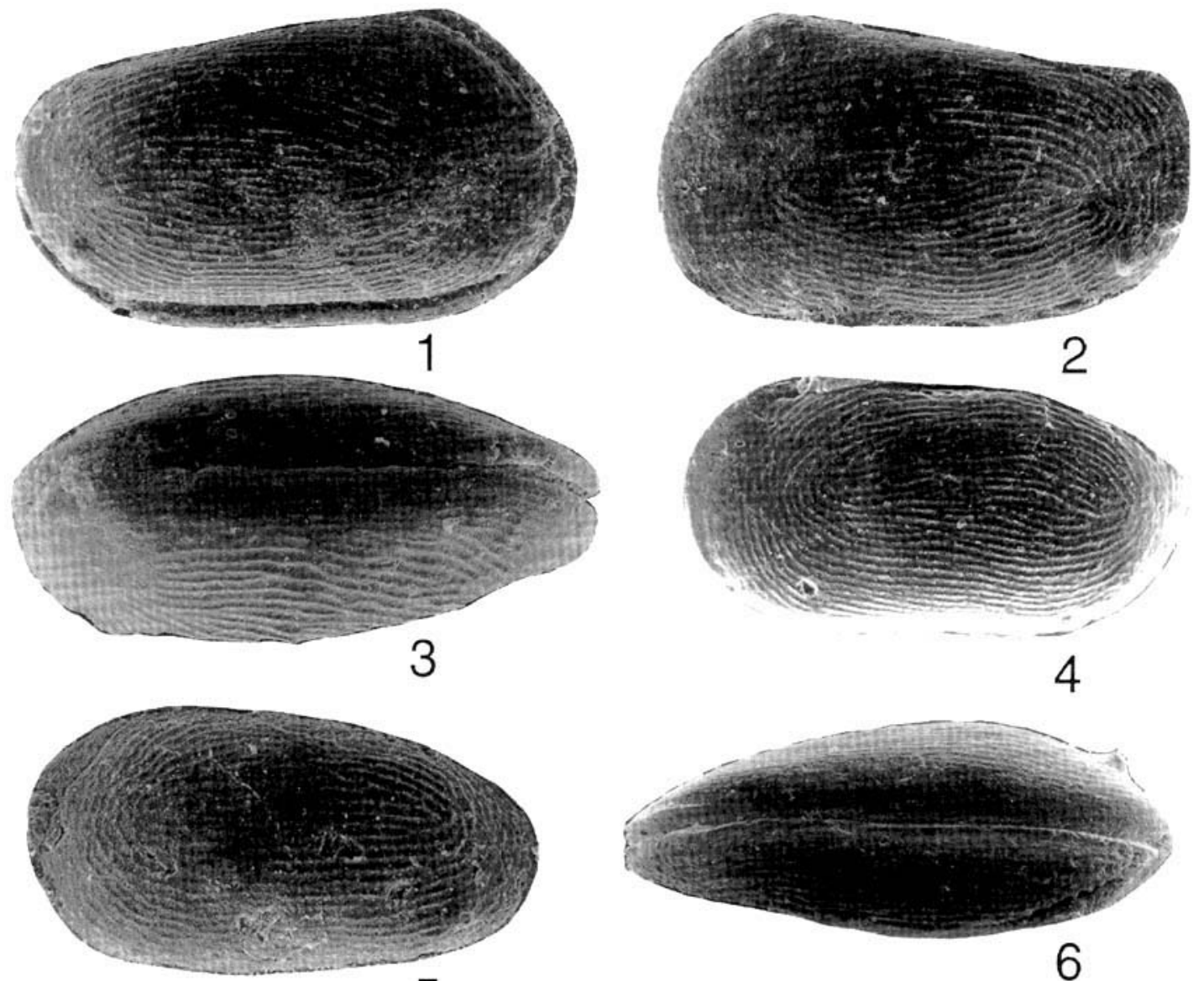

5
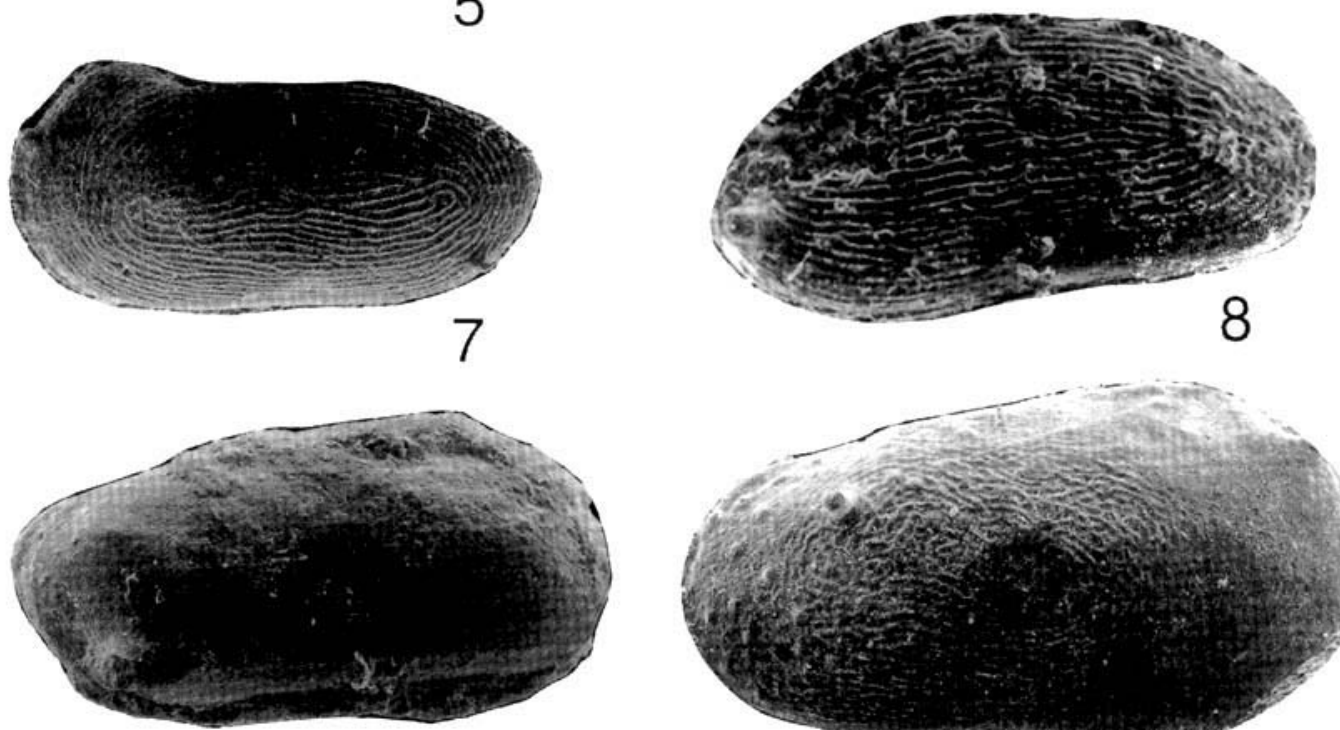

9

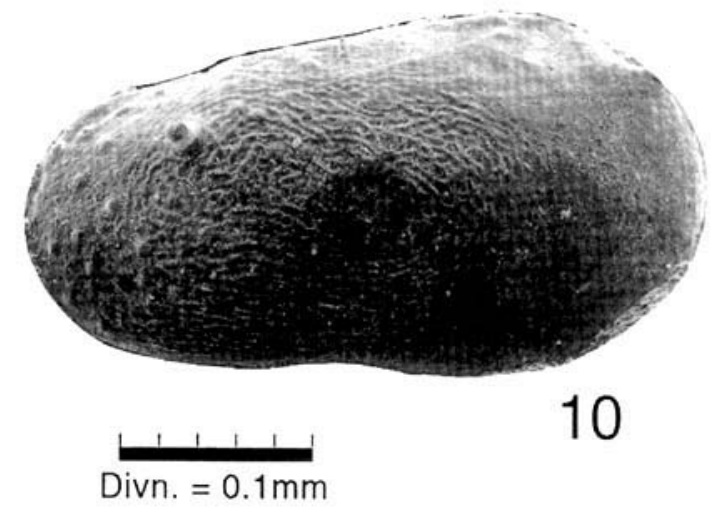


Graphiadactylloides $\mathbf{s p}$.

(Plate 3, fig. 9)

1995. González et al., Revista de la Asociación Geológica Argentina T.50 (1-4):40-46.

Material. One specimen IPM006/26, a steinkern.

Locality and horizon. Arroyo Pescado (Ap Iwan Farm), $100 \mathrm{~km}$ east of Esquel, Chubut province; upper siltstones, $100 \mathrm{~m}$ above the base.

Description. Carapace large, subrhomboidal in lateral view; dorsal border straight, ventral border slightly concave. Anterior and posterior ends rounded. LV larger than RV, with moderate $\mathrm{L} / \mathrm{R}$ overlap. Spines developed at postero-ventral corner in both valves.

Remarks. The sole specimen is a large steinkern $(1.55 \mathrm{~L} ; 0.73 \mathrm{H}$; $0.68 \mathrm{~W}$ ), with a subrhomboidal outline and posteroventral spines on both valves, features which are characteristic of the genus Graphiadactylloides. Because of its poor preservation, the above description is provisional, and the given outline and dimensions are approximate. The species possesses a similar lateral outline as the specimen illustrated by Sohn \& RochaCampos (1990) as Graphiadactyllis sp. aff G. yaurichambiensis Pribyl \& Pek, 1987, described from the Lower Permian of Bolivia. Sohn \& Rocha-Campos (1990: 124) noted that more than one species may be present in their collection of this taxon.

\section{Graphiadactylloides sp. aff. G. moreyi Green, 1963}

(Plate 3, fig. 10)

Material. One specimen, IPM006/25, external impression.

Type locality and horizon. As for Aurikirkbya tepuelensis n. sp. Description. Carapace large, subrhomboidal in lateral view; dorsal border straight, ventral border slightly concave. Anterior and posterior ends rounded. LV larger than $R V$, with slight $L / R$ overlap. Surface ornament in posterior half of carapace fingerprint pattern, anterior half smooth. Spines developed at postero ventral corner in both valves.

Remarks. As the sole specimen is a large poorly preserved RV (1. $78 \mathrm{~L} ; 0.75 \mathrm{H}$ ), the above description is provisional, and the given outline and dimensions are approximate. This species is distinguished from Graphiadactylloides patagoniensis sp. nov. by its different surface ornament; i.e. the posterior half of the carapace has a distinctive fingerprint pattern and the anterior half is smooth. In this respect, and in general outline, the specimen resembles $G$. moreyi; however, it lacks the characteristic anterior spine of G. moreyi.

\section{Order Eridostraca Adamczak, 1961}

Remarks. The taxonomic position and rank of this group is controversial. The Eridostraca may be an extinct group of marine branchiopods (Jones, 1968), or they may belong to the ostracod group Palaeocopida (Warshauer \& Berdan, 1982). The diagnoses that appear below have been extracted from a manuscript prepared by $\mathbf{P}$. J. Jones on the Eridostraca, which was submitted as a contribution to the revision of Palaeozoic Ostracoda for the Treatise of Invertebrate Paleontology (TIPPO) in 1997. As there appeared no chance that the TIPPO project would ever be completed, it was terminated in January
1999. The co-ordinators of the TIPPO project (D. J. Siveter and R. F. Lundin) returned the Eridostraca manuscript to the author, who will publish it elsewhere.

Family Rhabdostichidae Rusconi, 1954

[= Cryptophyllidae Adamczak, 1961]

Diagnosis. (After P. J. Jones, TIPPO manuscript). Eridostraca without admarginal structure; free margins of lamellae with Vshaped grooves; with short hinge-line which shifts ventrally during ontogeny to form epicline dorsum and large umbo; lateral outline suboval to postplete.

\section{Genus Cryptophyllus Levinson, 1951}

Type species. Eridoconcha oboloides Ulrich \& Bassler, 1923

Diagnosis. (After P. J. Jones TIPPO manuscript). Rhabostichidae with up to 15 lamellae. The chitinous lamellae is calcified, invaginated into the interior of the shell, and forms a ridge of solid chambers.

Stratigraphic range. Middle Ordovician (Llanvirn) to Early Carboniferous (Late Visean).

\section{Cryptophyllus sp.}

(Plate 2, Figs 5-8)

Material. Five specimens, four external impressions, IPM002/ 01-04 and one internal impression of umbonal area IPM002/02. Locality and horizon. As for Aurikirkbya tepuelensis n. sp. Description. Carapace small, lateral outline subtriangular to subovate, umbonate, with 7 lamellae and a spinous nauplioconch. Surface smooth. Adductorial ridge, well developed on the internal surface (expressed as a deep furrow in exfoliated specimen IPM002/ 02).

\begin{tabular}{|c|c|c|c|c|}
\hline $\begin{array}{l}\text { Dimensions. } \\
\text { Specimen }\end{array}$ & $L$ & $H$ & $H / L$ & Material \\
\hline IPM 002-02 & 0.46 & 0.29 & 0.63 & Pl. 2, fig. 5 \\
\hline IPM 002-04 & 0.43 & 0.35 & 0.81 & Pl. 2, fig. 8 \\
\hline IPM 002-03 & 0.45 & 0.34 & 0.75 & Pl. 2, fig. 7 \\
\hline IPM 002-0I & 0.42 & 0.27 & 0.64 & Pl. 2, fig. 6 \\
\hline
\end{tabular}

Remarks. Discrimination between species of Cryptophyllus is a difficult task because of the paucity of diagnostic features. The above description of the Patagonian species does not help in this regard. However, the presence of a spinous nauplioconch in Cryptophyllus sp. (Plate 2, fig. 7) is a feature that, at least, distinguishes this species from those described from the Early Carboniferous of Western Australia (Jones, 1962) and Libya (Bless \& Massa, 1982). Cryptophyllus sp. is probably a new species, but insufficient material is available. A comparison between the figures of Cryptophyllus sp. B (Jones, 1962, pl. 3, figs 5, 6) and Cryptophyllus sp. (Plate 2, fig. 5) on the one hand, and that of Hollinella? sp. 1 (Rossi de Garcia, 1972, fig. 1.1) on the other, indicates that the latter is probably an exfoliated specimen of a species belonging to Cryptophyllus.

\section{ACKNOWLEDGEMENTS}

The authors are indebted to Dr A. C. Taboada, Dr C. R. González and Mr M. A. Aredes, Fundación Miguel Lillo, for 
aid in fieldwork and suggestions. Dr N. Sabattini (Museo de La Plata) kindly provided rubber casts of Rossi de Garcia's material. The manuscript was improved as a result of reviews by Professor K. S. W. Campbell and Dr P. De Deckker (Department of Geology, The Australian National University), and computer graphic support for preparation of the plates and figures provided by Dr R. E. Barwick (Department of Geology, The Australian National University). Fieldwork was supported by PROGEBA (PID-BID 0584-Proyecto Paleo-Norpat); Fundación Miguel Lillo and by a National Geographic Society, Grant (\# 5372-94).

\section{Manuscript received 4 June 1996 Manuscript accepted 8 August 1999}

\section{REFERENCES}

Amos, A. J. 1958. Algunos spiriferacea y terebratulacea (Brach.) del Carbonifero superior del Sistema de Tepuel (Provincia de Chubut). Contribuciones cientificas. Facultad den Ciencias Exactas y Naturales Universidad Buenos Aires Geologia 2(3): 95-108.

Amos, A. J., Campbell, K. S. W. \& Goldring, R. 1960. Australosutra gen.nov. (Trilobita) from the Carboniferous of Australia and Argentina. Palaeontology, 3: 227-236.

Andreis, R. R., Archangelsky, S., Gonzàlez, C. R., Lopez Gamundi, O. \& Sabbattini, N., in collaboration with Acenolaza, G., Azcuy, C. L., Cortinas, J., Cuerda, A. \& Cuneo, R. 1987. Cuenca Tepuel-Genoa (VII). In Archangelsky, S. (Ed.), El Sistema Carbonifero en la República Argentina. Academia Nacional de Ciencias, Córdoba: $169-196$.

Archangelsky, S., Azcuy, C., Gonzàlez, C. R. \& Sabattini, N. 1987. Correlaciòn general de biozonas (XIII), pp. 281-291 y Edad de las biozonas(XIV), pp. 293-300. In Archangelsky, S. (Ed.), El Sistema Carbonifero en la República Argentina. Academia Nacional de Ciencias, Córdoba.

Azcuy, C. L., Sabattini, N. \& Taboada, A. C. 1990. Advances in the Lower Carboniferous Zonation of Argentina. Courier Forschungsinstitut Senckenberg, 130: 133-143.

Baldis, B. \& Rossi de Garcia, E. 1975. Ostracodes Devoniens Argentins associes a la Fauune Malvinokafrique. Proceedings of the 5th African Colloquium on Micropalaeontology, Addis-Ababa, 10-12 April. 1972. Ser. 7, 3: 57-91.

Baxter, J. W. \& Brenckle, P. L. 1982. Preliminary statement on Mississippian calcareous foraminferal successions of the Midcontinent (USA) and their correlation to western Europe. Newsletters on Stratigraphy, 11: 136-153.

Becker, G. 1978. Flachwasser-Ostracoden aus dem hohen Westfal Asturiens (Kantabrisches Gebirge, N-Spain). 1. Palaeocopida. Senckenbergiana lethaea, 59: 37-69.

Becker, G. 1990. Zur Morphologie und Taxonomie paläozoischer Ostracoda. Mit kritischen Bemerkungen zur Wertigkeit von Carapax-Merkmalen. Senckenbergiana lethaea 70: 147-169.

Becker, G. 1997a. Contributions to Palaeozoic Ostracod Classification [POC] 2. The Superfamily Kirkbyacea Ulrich \& Bassler, 1906. 1. Family Arcyzonidae Kesling, 1961. Neues Jahrbuch fur Geologie und Paläontologie Abhandlungen, 204: 111-126.

Becker, G. $1997 \mathrm{~b}$. Contributions to Palaeozoic Ostracod Classification [POC] 3. The Superfamily Kirkbyacea Ulrich \& Bassler, 1906. 2. Family Amphissitidae Knight, 1928. Neues Jahrbuch fur Geologie und Paläontologie Abhandlungen, 204: 127-140.

Becker, G. 1997c. Contributions to Palaeozoic Ostracod Classification [POC] 4. The Superfamily Kirkbyacea Ulrich \& Bassler, 1906. 3. Family Kirkbyidae Ulrich \& Bassler, 1906. Neues Jahrbuch fur Geologie und Paläontologie Abhandlungen, 205: 159-175.

Becker, G. 1997d. Contributions to Palaeozoic Ostracod Classification [POC] 5. The Superfamily Kirkbyacea Ulrich \& Bassler, 1906. 4. Family Kellettinidae Sohn, 1954. Neues Jahrbuch fur Geologie und
Paläontologie Abhandlungen, 205: 177-188.

Becker, G. 1998a. Contributions to Palaeozoic Ostracod Classification [POC] 1. 'Non-kirkbyacean' ostracods: Families Ordovizonidae n. fam., Kirkbyellidae Sohn, Scrobiculidae Posner, and Cardiniferellidae Sohn. With description of the new family Ordovizonidae $\mathrm{n}$. fam. and a new kirkbyellid genus: Eukempfella $\mathrm{n}$. gen. Sonderveroffentlichungen Geologisches Institut der Universitaet zu Köln [Kempf-Festschrift], 114: $29-57$.

Becker, G. 1998b. Contributions to Palaeozoic Ostracod Classification [POC] 8. The Superfamily Kirkbyacea Ulrich \& Bassler, 1906. 7. The drepanellid roots. Neues Jahrbuch fur Geologie und Paläontologie Abhandlungen, 209: 381-400.

Becker, G., Bless, M. J. M. \& Sanchez de Posada, L. C. 1977. Ostracoden: 79-97, In Requadt, H., Becker, G., Bless, M. J. M., Eickhoff, G. \& Sanchez de Posada, L. C. Mikrofaunen aus dem Westfal der spanischen West-pyrenaen (Ostracoda, Conodonta, Foraminifera). Neues Jahrbuch fur Geologie und Palaontologie Abhandlungen, 155(1): 65-107.

Benson, R. H. \& Collinson, C. 1958. Three ostracode fauna from lower and middle Mississippian strata of southern Illinois. Illinois Geological Survey Circular, 255: 1-26.

Bless, M. J. M. 1983. Late Devonian and Carboniferous ostracode assemblages and their relationship to the depositional environments. Bulletin de la Societe Belge de Geologie, 92(1): 31--53.

Bless, M. J. M. \& Massa, D. 1982. Carboniferous ostracodes in the Rhadamès Basin of western Libya: paleoecological implications and comparison with North America, Europe and the USSR. Revue de l'institut Francais du Pétrole, 37(1): 19-61.

Blumenstengel, H. 1975. Zur biostratigraphischen und faziellen Bedeutung der Ostracoden des Dinant von Rugen und Hiddensee. Zeitschrift Geologie Wissenschafen, 3(7): 951-969.

Brayer, R. C. 1952. Salem Ostracoda of Missouri. Journal of Paleontology, 26(2): 162-174.

Brodzikowski, K. \& van Loon, A. J. 1987. A systematic classification of glacial and periglacial environments, facies and deposits. Earth Science Reviews, 24: 297-381.

Brouwers, E. M. 1988a. Palaeobathymetry on the continental shelf based on examples using ostracods from the Gulf of Alaska. In De Deckker, P., Colin, J. P. \& Peypouquet, J. P. (Eds), Ostracoda in the Earth Sciences. Elsevier, Amsterdam: 55-76.

Brouwers, E. M. 1988b. Sediment transport detected from the analysis of ostracod population structure: an example from the Alaskan continental shelf. In De Deckker, P., Colin, J. P. \& Peypouquet, J. P. (Eds), Ostracoda in the Earth Sciences. Elsevier, Amsterdam: 231244.

Campbell, K. S. W. \& McKellar, R. G. 1969. Eastern Australian Carboniferous invertebrates: sequence and affinities. In Campbell, $\mathrm{K}$. S. W. (Ed.), Stratigraphy and Palaeontology: essays in Honour of Dorothy Hill. ANU Press, Canberra: 77-119.

Cooper, C. L. 1941. Chester ostracodes of Illinois. Illinois Geological Survey, Report of Investigations, 77: 1-101.

Copeland, M. J. 1982. Bathymetry of Early Middle Ordovician (Chazy) ostracodes, Lower Esbataottine Formation, District of Mackenzie. Bulletin of the Geological Survey of Canada, 347: 1-39.

Cuneo, R. 1987. Bibliografia (XVI). In Archangelsky, S. (Ed.), El Sistema Carbonifero en el República Argentina. Academia Nacional de Ciencias, Córdoba: 327-362.

Dickins, J. M. 1985. Late Paleozoic glaciation. BMR Journal of Australian Geology \& Geophysics, 9: 163-169.

Freytes, E. 1971. Informe geológico preliminar sobre la Sierra de Tepue. Depto. de Languiñeo y Tepuelches, Prov. de Chubut, inedit report Y.P.F., Buenos Aires.

González, C. R. 1969. Nuevas especies de Bivalvia del Paleozoico superior del Sistema de Tepuel, Provincia de Chubut (Argentina). Ameghiniana, 6: 236-250.

González, C. R. 1972a. La Formación las Salinas. Paleozoico superior de Chubut (República Argentina). Parte 1. Estratigrafia, facies y ambientes de sedimentación. Revista Asociación Geologica Argentina, 27(1): 95-115.

González, C. R. 1972b. La Formación las Salinas, Paleozoico superior de Chubut (Argentina). Parte II. Bivalvia: taxinomia y paleoecologva. Revista Asociación Geológica Argentina, 27(2): 188-213. 
González, C. R. 1975a. Promytilus patagonicus nov. sp. (Mytilidae, Bivalvia), del Paleozoico superior de El Molle, provincia de Chubut (Argentina). Actas $I^{\circ}$ Congreso Argentino de Paleontologva $y$ Bioestratigrafva, 1: 329-339.

González, C. R. 1975b. Nuevos Bivalvia de la Formacion las Salinas. Paleozoico superior de Chubut, Argentina. Actas $l^{\circ}$ Congreso Argentino de Paleontologia y Bioestratigrafia, 1: 341-355.

González, C. R. 1977. Bivalvos del Carbónico superior del Chubut, Argentina. Acta Geologica Lilloana, 14: 105-147.

González, C. R. 1978. Orbiculopecten gen.nov. (Aviculopectinidae, Bivalvia), from the upper Carboniferous of Patagonia, Argentina. Journal of Paleontology, 52: 1086-1092.

González, C. R. 1981. El Paleozoico superior marino de la República Argentina, biostratigrafía y paleoclimatología. Ameghiniana, 18: 51-65.

González, C. R. 1984. Rasgos paleogeográficos del Paleozoico superior de Patagonia. Actas IX Congreso Argentino de Paleontología y Bioestratigrafia, 1: 181-205.

González, C. R. 1987. Nuevas faunas de invertebrados del Carbónico inferior de la República Argentina. Abstract Annual Meeting of the Working Group Project PIGG $n^{\circ}$ 211. Santa. Cruz de la Sierra. Bolivia: 66-68.

González, C. R. 1990. Development of the Late Paleozoic glaciations of the South American Gondwana in western Argentina. Palaeogeography, Palaeoclimatology, Palaeoecology, 79: 275-287.

González, C. R. 1993. Late Paleozoic faunal succession in Argentina. Comptes Rendus XII Congrés International de la Stratigraphie et Géologie du Carbonifère et Permien, 1991, 1: 537-550.

González, C. R., Taboada, A. C., Diaz Saravia, P. G. \& Aredes, M. A. 1995. El Carbónico del sector norocccidental de la provincia del Chubut. Revista Asociación Geológica Argentina, 50: 40-46.

González Bonorino, G., Rafine, G., Vega, V. \& Guerin, D. 1988. Ambientes de plataforma néritica dominada por tormentas en la sección glacigénica del Grupo Tepuel (Paleozoico superior), en las sierras de Tepuel y Tecka, Chubut noroccidental, Argentina. Revista Asociación Geológica Argentina, 43: 239-252.

Gramm, M. N. 1976. The interrelation brteen the Palaeozoic ostracodes Roundyella and Scrobicula. Geologiska Föreningens $i$ Stockholm Förhandlingar, 98: 217-226.

Green, R. 1963. Lower Mississippian Ostracodes from the Banff Formation, Alberta. Research Council of Alberta Bulletin, 11: 1-201.

Gründel, J. 1975. Neues Ostracoden der Healdiacea und Quasillitacaea aus dem Dinant der Insel Rugen. Zeitschrift Geologie Wissenschafen 3: 971-983.

Harlton, B. H. 1929. Some Upper Mississippian (Fayetteville) and Lower Pennsylvanian (Wapanucka-Morrow) Ostracoda of Oklahoma and Arkansas. American Journal of Science, series 5, 18(105): 254 270.

Hughes, C. P., Rickards, B. R. \& Williams, A. 1980. The Ordovician fauna from the Contaya Formation of eastern Peru. Geological Magazine, 117: 1-21.

Jones, P. J. 1962. The ostracod Genus Cryptophyllus in the Upper Devonian and Carboniferous of Western Australia. Bureau of Mineral Resources, Geology \& Geophysics, Bulletin, 62: 1-37.

Jones, P. J. 1968. Upper Devonian Ostracoda and Eridostraca from the Bonaparte Basin, north western Australia. Bureau of Mineral Resources, Geology \& Geophysics, Bulletin, 99: 1-109.

Jones, P. J. 1989. Lower Carboniferous Ostracoda (Beyrichicopida \& Kirkbycopa) from the Bonaparte Basin, north western Australia. Bureau of Mineral Resources, Geology \& Geophysics, Bulletin, 228: 197.

Keidel, J. 1922. Sobre la distribución de los dépositos glaciares del Pérmico conocidos en la Argentina y su significación para la estratigrafia del hemisferio austral. Boletin Academia Nacional de Ciencias, 25: 239-368.

Lane, H. R., 1978. The Burlington Shelf (Mississippian, north-central United States). Geologica et Palaeontologica, 12: 165-176.

Leiggi, P. 1989. The use of vinyl polysiloxanes and quick setting epoxies in paleontology. Journal of Paleontology, 63: 256.

Loranger, D. M. 1963. Devonian Microfauna from Northeastern Alberta. Part 1, Ostracoda. Orders Leperditocopida and Palaeocopida. Published privately by author: $55 \mathrm{pp}$.

Mariñelarena, M. P. de 1970. Algunas especies de Paraconularia Sinclair del 'Sistema de Tepuel' y sus relaciones con las faunas del hemisfer io austral. Ameghiniana, 7: 139-150.

Melnyk, D. H. \& Maddocks, R. F. 1988. Ostracode biostratigraphy of the Permo-Carboniferous of central and north-central Texas, part I: paleoenvironmental framework. Micropaleontology, 34: 1-20.

Miller, A. K. \& Garner, M. F. 1953. Upper Carboniferous Goniatites fron Argentina. Journal of Paleontology, 27: 821-823.

Olempska, E. 1981. Lower Carboniferous ostracodes of the Holy Cross Mountains, Poland. Acta Palaeontologica Polonica, 26: 33-53.

Olempska, E. 1997. Changes in benthic ostracod assemblages across the Devonian-Carboniferous boundary in the Holy Cross Mountains, Poland. Acta Palaeontologica Polonica, 42: 291-332.

Page, R. F., Limarino, C. O., López Gamundi, O. \& Page, G. 1984 Estratigrafia del Grupo Tepuel en su perfil tipo y en la región de El Molle, provincia de Chubut. Actas $9^{\circ}$ Congreso Geológico Argentino, 1: $619-632$.

Petriella, B. T. \& Arrondo, O. G. 1978. Presencia de Archaeosigillaria conferta (Frenguelli) Menéndez el Carbónico inferior de Argentina. Ameghiniana, 15: 406-408.

Riccardi, A. \& Sabattini, N. 1975. Cephalopoda from the Carboniferous of Argentina. Palaeontology, 18: 117-136.

Roberts, J., Claoué-Long, J., Jones, P. J. \& Foster, C. B. 1995. SHRIMP zircon age control of Gondwanan sequences in Late Carboniferous and Early Permian Australia. In Dunay, R. E. \& Hailwood, E. A (Eds). Non-biostratigraphical Methods of Dating and Correlation. Geological Society, London, Special Publication, 89: 145-174.

Rossi de Garcia, E. 1972. Ostrácodos del Carbonifero del Sistema de Tepuel. Revista Española de Micropaleontologia, 4: 27-29.

Sabattini, N. 1972. Los Fenestellidae, Acanthocladiidae y Rhabdomesidae (Bryozoa, Cryptostomata) del Paleozoico superior de San Juan y Chubut. Revista del Museo de la Plata Nueva Serie, Seccion Paleontologia, 6, 255-377.

Sabattini, N. 1978. Gastrópodos carbónicos y pérmicos del Grupo Tepuel (Provincia de Chubut, Argentina). Obra Centenario Museo de la Plata, 5: 39-62.

Sabattini, N. 1983. Especies de Septatopora Engel (?Bryozoa) del Carbonico de la Provincia de Chubut, Argentina. Ameghiniana Revista de la Asociacion Paleontologica Argentina, XX(1-2): 61-71.

Sabattini, N. \& Noriat, S. 1969. Algunos Gastrópodos de las Superfamilias Euomphalacea, Pleurotomariacea y Platyceratacea del Paleozoico superior de Argentina. Ameghiniana, 6: 98-118.

Schallreuter, R. E. L. 1981. Ordovizische Ostrakoden Argentiniens. Mitteilungen aus dem Geologisch-Palaontologisches Institut der Universität Hamburg, 51: 9-21.

Schallreuter, R. E. L. 1996. Ordovizische Ostrakoden Argentiniens II. Mitteilungen aus dem Geologisch-Palaontologisches Institut der Universität Hamburg, 79: 139-169.

Shaver, R. H. \& Smith, S. G. 1974. Some Pennsylvanian kirkbyacean ostracods of Indiana and Midcontinent Series terminology. Department of Natural Resources, Indiana Geological Survey Report of Progress, 31: 1-67.

Siveter, D. 1982. Casts illustrating fine ornament of a Silurian ostracod. In Bate, R. H., Robinson, E. \& Sheppard, L. M. (Eds), Fossil and Recent Ostracods, British Micropalaeontological Society and E. Horwood, Chichester: 105-122.

Sohn, I. G. 196la. Family Aechminellidae. In Moore, R. C. \& Pitrat, C. W. (Eds), Treatise on Invertebrate Paleontology: Part Q. Arthropoda 3. Ostracoda. Geological Society of America and University of Kansas Press, New York and Lawrence, Kansas: Q 125-127.

Sohn, I. G. 1961b. Family Scrobiculidae. In Moore, R. C. \& Pitrat, C. W. (Eds), Treatise on Invertebrate Paleontology: Part Q. Arthropoda 3. Ostracoda. Geological Society of America and University of Kansas Press, New York and Lawrence, Kansas: Q 168-169.

Sohn, I. G. 1962. [imprint 1961]. Aechminella, Amphissites, Kirkbyella, and related genera. United States Geological Survey Professional Paper, 330-B: $107-173$.

Sohn, I. G. 1983. Ostracodes of the 'Winifrede Limestone' (Middle Pennsylvanian) in the region of the proposed Pennsylvanian System stratotype, West Virginia. Bulletin of American Paleontology, 84(316): $1-53$.

Sohn, I. G. \& Rocha-Campos, A. C. 1990. Late Paleozoic (Gondwanan) ostracodes in the Corumbatai Formation, Parana Basin, Brazil. Journal of Paleontology, 64: 116-128. 
Suero, T. 1948. Descubrimiento del Paleozoico superior en la zona extraandina del Chubut. Boletín Informaciones Petroleras, 287: 31-48.

Taboada, A. C. 1989. La fauna de la Formación El Paso, Carbonífero inferior de la Precordillera sanjuanina. Acta Geologica Lilloana, 17: 113-129.

Valencio, D. A. 1973. El significado estratigráfico y paleogeográfico de los estudios paleomagnéticos de formaciones del Paleozoico superior y del Mesozoico inferior de América del Sur. Actas $5^{\circ}$ Congreso Geológico Argentino, 5: 71-79.

Warshauer, S. M. \& Berdan, J. M. 1982. Palaeocopid and podocopid Ostracoda from the Lexington Limestone and Clays Ferry Formation (Middle and Upper Ordovician) of central Kentucky. United States Geological Survey Professional Paper, 1066-H: 1--80. 